Ольга Геннадьевна Парамузова

\title{
ПРАВОВАЯ ПРИРОДА АКТОВ МЕЖДУНАРОДНОГО АГЕНТСТВА ПО АТОМНОЙ ЭНЕРГИИ В УСЛОВИЯХ СОВРЕМЕННОГО МЕЖДУНАРОДНОГО ПРАВОПОРЯДКА
}

Начиная разговор о правовой природе актов МАГАТЭ, к каким бы выводам мы не пришли в ходе исследования, необходимо сразу оговориться, что разработкой подобных актов занимаются и другие международные (межправительственные) организации, скажем: ЕС (Европейский Союз), ВМО (Всемирная метеорологическая организация), ИМО (Международная морская организация), ИКАО (Международная организация гражданской авиации), ВОЗ (Всемирная организация здравоохранения) и т.д.

Однако, учитывая исключительную роль Агентства в деле поддержания международной безопасности, \{можно, даже провести некую параллель с деятельностью Совета Безопасности ООН, в том плане, что Совет Безопасности главный орган, ответственный за поддержание международной безопасности, и его правосубъектность в данной сфере носит универсальный характер, в то время как правосубъектность МАГАТЭ - ограничена его Уставом и носит специальный характер $\}$ требуется констатировать особую значимость нормотворческой деятельности МАГАТЭ.

Ст. III А. 6 Устава прямо предусматривает издание норм безопасности в качестве одной из основных функций Агентства. Причем нормы безопасности должны применяться как к собственной его деятельности, так и к деятельности других организаций и лиц, при которой используются материалы, услуги, оборудование, технические средства, предоставляемые МАГАТЭ, или по его требованию, или под его контролем, или наблюдением, и обеспечить, по требованию сторон, применение этих норм к деятельности, проводимой на основании любого двустороннего или многостороннего соглашения, или, по требованию того или иного государства, к любому виду деятельности этого государства в области атомной энергии. 
Такие правила и нормы безопасности, издаваемые МАГАТЭ, принято называть «стандартами здоровья и безопасности», которые необходимо отличать от «мер по здравоохранению и безопасности». В чем же их различие?

Под «стандартами здравоохранения и безопасности» Совет управляющих МАГАТЭ понимает «...нормы, правила или рекомендации, установленные для того, чтобы охранять здоровье и свести к минимуму опасность для жизни и имущества». ${ }^{1}$ Стандарты утверждаются Советом управляющих и должны удовлетворять определенным требованиям: быть согласованы с нормами, выработанными другими международными организациями, компетенция которых в соответствующих областях является признанной; быть приемлемы для международного сообщества. Меры по здравоохранению и безопасности МАГАТЭ, по определению Совета управляющих, - «...действия, процедуры или условия...», применяемые для обеспечения выполнения стандартов. какова же юридическая природа стандартов МАГАТЭ?

Рассмотрение данного вопроса целесообразно начать с определения понятия «международные стандарты», как таковые. Можно предложить следующее определение: международный стандарт - это правило поведения, имеющее общий характер, принимаемое, в большинстве своем, как правило, компетентными международными организациями и содержащее в себе минимальный, с точки зрения необходимости, набор прав, правомочий и требований в той или иной области деятельности, которые государства, при наличии определенных условий, закрепляют в национальном законодательстве и, тем самым, делают их обязательными. При этом ничто не препятствует государствам предоставить больший объем прав, правомочий и требований, чем это предусмотрено в стандарте.

На наш взгляд, можно выделить следующие виды международных стандартов:

1) Обязательные для государств правила и требования безопасности, закрепленные в международных договорах, в число которых входят: а) договоры, содержащие общепризнанные нормы международного права или, другими словами, императивные нормы общего международного права (jus cogens). Согласно ст. 53 Венской конвенции о праве международных договоров 1969 г., императивная норма общего международного права (jus cogens) принимается и признается международным сообществом в целом и может изменяться последующей нормой общего международного права, носящего такой же характер. ${ }^{2}$ Такие договоры

1 См.: Док. МАГАТЭ INFCIRC/18/RevJ.

2 См.: Международное публичное право. Сборник доку ментов/сост, К.А. Бекяшев, А.Г. Ходаков. Т. 1. М., 1996. С. 79. 
подлежат исполнению всеми без исключения государствами, отклонение от них не допустимо; б) региональные международные договоры; с) двусторонние и многосторонние международные договоры.

В ряде стран требуется издание специальных внутригосударственных актов для трансформации норм международного права в национальное законодательство. Что касается Российской Федерации, то, в соответствии с п. 4 ст. 15 конституции РФ 1993 г., «... общепризнанные принципы и нормы международного права и международные договоры, заключенные Российской Федерацией, являются составной частью ее правовой системы...», то есть на территории России установлен порядок их прямого действия. Согласно смыслу данной статьи, указанные выше международные договоры (а значит и содержащиеся в них стандарты безопасности) при условии прохождения всех стадий заключения международного договора, а также при выполнении особых требований к вступлению договора в силу, вытекающих из его текста, не нуждаются в особом закреплении во внутреннем законодательстве Российской Федерации и не требуют принятия специальных законов.

Применительно к предмету нашего исследования можно назвать следующие международные договоры, содержащие обязательные стандарты (правила и требования ядерной безопасности и радиационной защиты): конвенция о физической защите ядерного материала 1980 г; конвенции об оперативном оповещении и помощи в случае ядерной аварии или радиационной аварийной ситуации 1986 г.; конвенция о ядерной безопасности 1994 г. и др.

2) Регламенты, принимаемые международными организациями (ЕС, ИМО, ИКАО, МАГАТЭ и др.). ${ }^{3}$ Такие правила становятся обязательными после их закрепления во внутреннем законодательстве государств или в международном договоре.

Попытаемся разобраться в чем суть правил (стандартов безопасности), принимаемых Международным агентством по атомной энергии.

Правила Агентства - акт межгосударственной организации. А последние могут участвовать в создании норм международного права в следующих случаях: I) самостоятельно принимать решения нормоустановительного характера, если таким правом они наделены; 2 ) совместно с другими государствами, международными организациями заключать международные договоры. Так, ст. III Венской конвенции о праве международных договоров 1969 г. пред-

3 См., например: Малинин С.А., Ковалева Т.М. Соглашения международных межправительственных организаций: функциональный анализ применительно к международной морской организации//Вестник СанктПетербургского университета. Серия 6. 1992. Выпуск 4. С. 93-101.

4 См: Малинин С.А. О правотворческой деятельности межгосударственных организаций//Советский ежегодник международного права, 1971.М., 1973. С. 178-179. 
усматривает, что международные организации могут заключать международные соглашения, которые по своей природе - суть международные договоры, а по своей юридической силе не отличаются от соглашений, заключенных между типичными субъектами международного права; 3 )давать рекомендации по закреплению определенных положений в международных договорах или во внутреннем законодательстве государств. Если говорить о решениях международных организаций, то они играют, как правило, вспомогательную роль и носят рекомендательный характер. По внутриорганизационным вопросам решения, хотя и носят обязывающий характер, но не являются во всех случаях нормами международного права. Дело в том, что они относятся к так называемому внутреннему праву той или иной организации, а нормы этого права не однозначны по своей юридической природе. ${ }^{6}$

В МАГАТЭ разработкой стандартов в области радиационной защиты и ядерной безопасности занимаются два органа: Генеральная конференция и Совет управляющих. Совет управляющих, например, может осуществлять достаточно широкий круг действий без получения на то санкций Генеральной конференции. В частности, он одобряет все проекты соглашений о гарантиях, рассматривает любые случаи нарушения гарантий, сообщает о них Совету Безопасности и Генеральной Ассамблее ООН, принимает «корректирующие меры» для ликвидации нарушений и т.д. Однако необходимо сделать оговорку о том, что решения в связи с осуществлением указанных действий либо носят внутриорганизационный характер, либо являются исполнительными постановлениями.

Строго говоря, Совет управляющих - исполнительный орган МАГАТЭ и не может принимать постановления, содержащие общие нормы международного права. Данный вывод вытекает из анализа Устава Агентства (cт. V. п. D,F), в соответствии с которым Генеральная конференция может отменить любое решение Совета управляющих. Генеральная конференция обладает высшей прерогативой власти и может решать многие вопросы, как то: выборы членов Совета управляющих, прием в члены, утверждение бюджета и др.(ст. V. п. Е Устава МАГАТЭ). Решения по ним касаются конкретных ситуаций и конкрет-

5 О правовой сущности договоров, заключаемых международными организациями см., например: Международные организации, М., 1994; Международные организации системы ООН. Справочник. М., 1990; Морозов Г.И. Международные организации. Некоторые вопросы теории. М., 1974; Шреплер Х.A. Международные организации. Справочник. М., 1995; Amerasinghe C.F. Principles of the Institutional Law and Organizations Cambridge, 1996; Vandervort Thomas L.R. International Law and Organization. London, 1997; Sato Tetsuo. Evolving Constitutions of International Organization. Dordrecht, 1996;Manual of International Law. Ed, by M. Sorensen. L-N.Y., 1968. Pp. 177-178; Chju H. The Capacity of International Organizations to Conclude Treaties and Special Legal Aspects of the Treaties so Concluded. The Hague, 1966

6 См.: Ковалева Т.М. Юридическая квалификация стандартов Международной морской организации/Актуальные вопросы морского права. М., 1990. С. 86-96; Маргиев В.И. Внутреннее право международных организаций. Владикавказ, 1995. 
Правовая природа актов Международного агентства по атомной энергии...

ных адресатов, то есть, не могут содержать правил, носящих характер правовых норм.

Одним из важных аспектов деятельности Агентства, безусловно, является разработка проектов многосторонних конвенций и административно-технических правил в области мирного использования атомной энергии (правила, peгламентирующие систему гарантий, правила безопасности при использовании радиоактивных материалов и др.)

Если участие МАГАТЭ в подготовке проектов конвенций можно с полным на то основанием отнести к начальной стадии процесса создания норм международного права, то определение юридической природы административнотехнических актов требует серьезных размышлений, принимая во внимание тот факт, что в правовой литературе до сих пор не сложилось единого мнения на этот счет. ${ }^{7}$

Правила безопасности, как считает Д.А.Фишер, не должны быть обязательными, а скорее служат руководством по обеспечению безопасности при обращении с радиоактивными материалами, ${ }^{8}$ то есть, подобные документы суть международные рекомендации.

Тогда возникает другой вопрос: что есть рекомендация и как относиться к такому понятию как рекомендательная норма?

Приверженцем идеи реальности существования наряду с обязательными нормами международного права и рекомендательных норм является Г.М. Вельяминов. ${ }^{9}$ По его мнению, рекомендательная норма обладает тем же набором характерных признаков, что и обязательная; единственное ее исключение состоит в том, что предусматриваемые ею правоотношения возникают, изменяются или прекращаются не в силу самой нормы, а лишь в результате предъявленных волеизъявлений субъектов права под воздействием целевой установки нормы.

Г.И. Тункин подвергнул большому сомнению факт наличия в международном праве такого явления как рекомендательная норма. ${ }^{10}$ Мало того, Г.И. Тункин считал, что регламенты «...являются по своему существу международ-

7 De Burga G. EC Law. Text, Cases and Materials. London, 1998, Weatherill S. Cases and Materials on EC Law. London, 1996.

8 Fisher D.A.V. The International Atomic Energy Agency. Nuclear Law for a Developing World IAEA. Legal Series №5.

9 Вельяминов Г.М. О понятии нормы международного право//Советский ежегодник международного права. 1971.М., 1973. С. 138-139.

10 Тункин Г.И. XXVсъезд КПСС и основные проблемы советской науки международного права. //Советский ежегодник международного права, 1976. М.,1978. С. 17. 
ными договорами». ${ }^{11}$ Такого же мнения придерживаются: А.Н, Верещагин, ${ }^{12}$ Е.А. Шибаева, ${ }^{13}$ Г.В. Игнатенко. ${ }^{14}$

Рассмотренная выше точка зрения является все-таки спорной, хотя и имеет право на своё существование. По крайней мере, реально существуют программные нормы, которые иначе чем рекомендательными не назовешь. Программные нормы, будучи по своей природе рекомендациями, тем не менее, обязательны для государств с точки зрения перспективного регулирования. Например, конечная цель Московского договора о запрещении испытаний ядерногооружия в трех средах 1963 г. -- всеобщее и полное разоружение.

Однако, сказанное вовсе не означает, что административно-регламентационные акты являются юридически обязательными. Правила административнорегламентационных актов, принимаемых международными организациями, а значит и правила безопасности МАГАТЭ, так называемые стандарты здравоохранения и безопасности, на наш взгляд, носят рекомендательный характер, они не являются нормами, ибо у них отсутствует такой обязательный признак нормы международного права, как обязательность. Для приобретения подобного качества стандарты Агентства должны быть так или иначе одобрены или, иными словами, санкционированы государствами, что может быть осуществлено в различных формах. ${ }^{15}$ При этом важно отметить, что процедура одобрения стандартов является более упрощенной по сравнению с процессом трансформации международных норм в национальное законодательство (в тех государствах, где отсутствует прямое действие международного права).

Исключение из данного правила, пожалуй, составляют акты, принимаемые в рамках Европейского Союза (ЕС). Регламенты ЕС действительно обладают юридически обязательной силой для государств-членов. Однако рассмотрение подобных актов - предмет самостоятельного научного исследования.

\footnotetext{
11 Тункин Г.И. Теория международного права. М., 1971. С. 121.

12 Актуальные вопросы международного воздушного права. М., 1973. С. 72.

13 Шибаева Е.А Специализированные учреждения ООН (Международно-правовые аспекты). М., 1966. C.104-105.

14 Игнатенко Г.В. - Рец. Г.И. Тункин Теория международного права// Советский ежегодник международного права. 1971. М., 1973. С. 399.

15 См. подробнее: Малинин С.А., ковалева Т.М. Правовая природа административно-регламентационных актов, издаваемых межгосударственными организациями// Малинин С.А. Избранное. СПб., 2003. С. $72-73$.
} 


\section{LEGAL NATURE OF IAEA (INTERNATIONAL ATOMIC ENERGY AGENCY)'S ACTS IN FRAMES OF MODERN INTERNATIONAL LEGAL ORDER}

This article deals with some of the problems associated with modern international-legal science as practiced in international relations, namely, the interpretation and determination of the legal nature of IAEA's acts (standards, rules, administrative safety regulations and others). The problems of possible military nuclear activity by some states are very difficult and sophisticated. These problems must be decided in the near future. The role of IAEA in such a modern geopolitical situation concerning the efficiency of the non-proliferation treaty' regime, is really exclusive. Determining the legal nature of IAEA's acts, their obligatory or recommendatory character, allows the international community to price the cost of non-proliferation' perspectives and international security.

Key words:

Non-proliferation mechanizm, nuclear disarmament, international safety, culture of nuclear security, safety standards of the IAEA, rules and norms of the IAEA. 